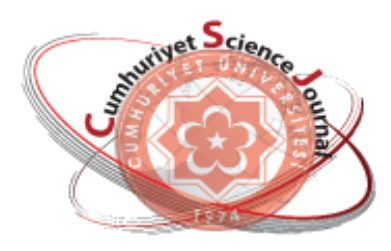

e-ISSN: 2587-246X

ISSN: $2587-2680$

\section{Cumburiyet Scionce Journal esy}

Cumhuriyet Sci. J., Vol.40-1(2019) 35-41

\title{
Histopathological Effects of Fonofos on Gills of Zebrafish (Danio rerio)
}

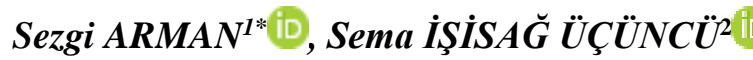 \\ ${ }^{I}$ Sakarya University, Faculty of Arts and Sciences, Department of Biology, Sakarya, TURKEY \\ ${ }^{2}$ Ege University, Faculty of Science, Department of Biology, Izmir, TURKEY
}

Received: 17.05.2018; Accepted: 22.01.2019

http://dx.doi.org/10.17776/csj.424499

\begin{abstract}
Organophosphate pesticides are commonly used to increase agricultural efficiency worldwide. However, it has been proved that these chemicals generally do not show target specificity and non-target vertebrate organisms are adversely affected by pesticide exposure. The aim of the present study was to examine the potential harmful effects of fonofos, an organophosphate insecticide, on the gill tissues of zebrafish (Danio rerio). Adult zebrafish were exposed to 1, 2 and $4 \mathrm{mg} / \mathrm{L}$ fonofos for 96 hours. Gill tissues were removed, fixed with Bouin's fluid and embedded in paraffin. $5 \mu \mathrm{m}$ serial sections were stained with hematoxylin-eosin, Gomori trichrome or periodic acid-Schiff. Samples were investigated by light microscopy and histological alterations were compared with the $0.1 \%$ dimethyl sulfoxide (DMSO) exposed solvent control samples. Fonofos caused epithelial lifting, curling of secondary lamellae, desquamation, epithelial hyperplasia, and lamellar fusion in the gills. Gills showed distinct histopathological changes through fonofos exposure. It was determined that fonofos is a threat to non-target organisms living in aquatic ecosystems.
\end{abstract}

Keywords: Fonofos, insecticide, gill, histopathology, zebrafish, Danio rerio

\section{Fonofos'un Zebra Balığı (Danio rerio) Solungaçlarındaki Histopatolojik Etkileri}

\begin{abstract}
Özet. Organofosfatlı pestisitler dünya çapında tarımsal verimliliği artırmak için yaygın olarak kullanılmaktadır. Ancak, bu kimyasalların genel olarak hedef özgüllüŭg̈ göstermediği ve hedef dışındaki omurgalı canlıların da pestisit maruziyetinden etkilendikleri ortaya konmuştur. Bu çalışmanın amacı, organofosfatlı bir insektisit olan fonofosun zebra balığının (Danio rerio) solungaç dokularındaki potansiyel zararlı etkilerini araştırmaktır. Ergin zebra balıkları 96 saat boyunca 1, 2 ve $4 \mathrm{mg} / \mathrm{L}$ fonofosa maruz bırakıldı. Solungaçlar çıkartılarak Bouin sıvısında tespit edildi ve parafine gömüldü. $5 \mu \mathrm{m}$ kalınlıktaki kesitler hematoksilen eozin, Gomori trikrom veya periyodik asit Schiff boyaları ile boyandı. Örnekler ışık mikroskobunda incelenerek histolojik değişimleri \%0,1 dimetilsülfoksit (DMSO) uygulanan çözücü kontrol grubu örnekleriyle karşılaştırıldı. Fonofos solungaçlarda, epitel dokuda kalkma, sekonder lamellerde kıvrılma, deskuamasyon, epitelyal hiperplazi ve lamellar füzyona yol açtı. Solungaçlar fonofos maruziyeti ile belirgin histopatolojik farkll1ıklar gösterdi. Fonofosun sucul ekosistemlerde yaşayan hedef dışı organizmalar için bir tehdit oluşturduğu belirlenmiştir.
\end{abstract}

Anahtar Kelimeler: Fonofos, insektisit, solungaç, histopatoloji, zebra balığ

\section{INTRODUCTION}

It is an essential concern to develop agricultural productivity to support the food requirement of the increased human population. Pesticides are being commonly used worldwide for this purpose and manufacturing industry progresses to satisfy the demand. There are various classes of pesticides based on their chemical structures such as organochlorines, organophosphates and more 
recently developed carbamates, pyrethroids, and neonicotinoids. Persistent organochlorines have substantially fallen into disuse; however, it is predicted that organophosphates $(\mathrm{OP})$ will be used widely in the near future due to their low cost, low cumulative ability, and short-term persistence in nature [1,2]. On the other hand, low-persistence obliges farmers to do repeated applications, and this case makes OP pesticides get through to water sources [3]. It is pointed out that OPs are harmful to fish [4-6]. Researches focusing on the investigations of adverse effects of OP pesticides on teleost fish have been conducting for a long time.

Fonofos (O-ethyl $\quad S$-phenyl ethylphosphonodithioate) is an OP insecticide applied directly to soil to control various worms that are hazardous for corn, sugarcane, peanuts, and tobacco $[7,8]$.

Zebrafish (Danio rerio) is a model organism for many research areas such as developmental biology, genetics, and toxicology. Small size, diversified adaptability, and low cost make zebrafish a useful experimental material $[9,10]$.

Teleost gills are responsible for the gas transfer, osmoregulation, acid-base balance, and ionic regulation. In toxicological studies, gills are helpful tools to observe the effects of environmental pollutants [11].

The aim of this study is to examine the harmful effects of fonofos on gills of zebrafish by histological techniques.

\section{MATERIALS AND METHODS}

The experiment was conducted in accordance with the guidelines for animal research established by the Local Ethics Committee of Animal Experiments at Ege University (the date and the number of the document: 2016-090).
Adult zebrafish were obtained from a commercial fish dealer in Izmir. They were acclimated under laboratory conditions for two weeks before the treatment. They were maintained in a glass aquarium with dechlorinated tap water at $26 \pm 2{ }^{\circ} \mathrm{C}$ and natural photoperiod regime. They were fed with artemia twice a day.

Fonofos (99.5\%) (CAS No: 944-22-9) and DMSO $(\geq 99.5 \%)$ were purchased from Sigma-Aldrich. The stock solution was freshly prepared before the experiment by solving fonofos in DMSO $(0.1 \%)$. Treatment concentrations (1,2 and $4 \mathrm{mg} / \mathrm{L}$ fonofos) were diluted from the stock solution. The control group samples were treated with the same concentration of DMSO $(0.1 \%)$ of the stock solution. Five fish were used for each treatment and the control groups. They were exposed to the chemical for $96 \mathrm{~h}$. Fish were anaesthetized with MS222 (tricaine methanesulfonate), gill tissues were removed, fixed with Bouin's fluid [12] for 24 $\mathrm{h}$ and embedded in paraffin. $5 \mu \mathrm{m}$ serial sections were stained with Mayer's hematoxylin-eosin (HE), Gomori trichrome (GT) or periodic acid-Schiff (PAS) [13]. Histological alterations were investigated by light microscopy. Micrographs were taken with Zeiss Axio Scope A1 (Carl Zeiss, Germany) equipped with Zeiss Axiocam ERc5s.

\section{RESULTS}

No histological anomaly was observed in the control samples. Gill filaments were rich in blood vessels consisted of primary lamellae that had central cartilage axis and secondary lamellae which were covered by squamous epithelium. Supportive pillar cells were observed. Additionally, central veins were noticed clearly (Fig. 1.).

$1 \mathrm{mg} / \mathrm{L}$ fonofos treatment group samples showed slightly curled secondary lamellae and epithelial hyperplasia (Fig. 2.). 

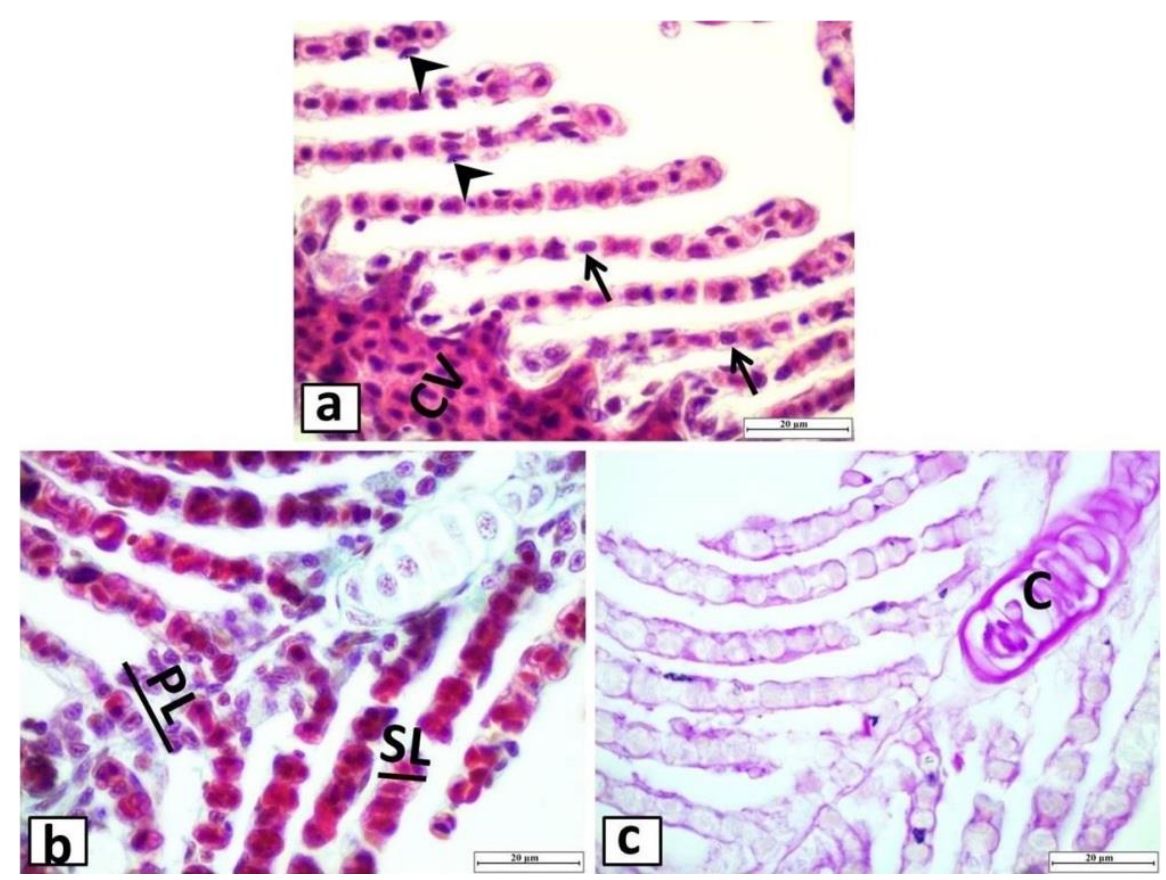

Figure 1. Gill sections of zebrafish from the control group. a) Central vein (CV), pillar cells (arrows), and epithelial cells (arrowheads), H-E, X100. b) Primary lamella (PL), and secondary lamella (SL), GT, X100. c) Cartilage (C), PAS, X100.

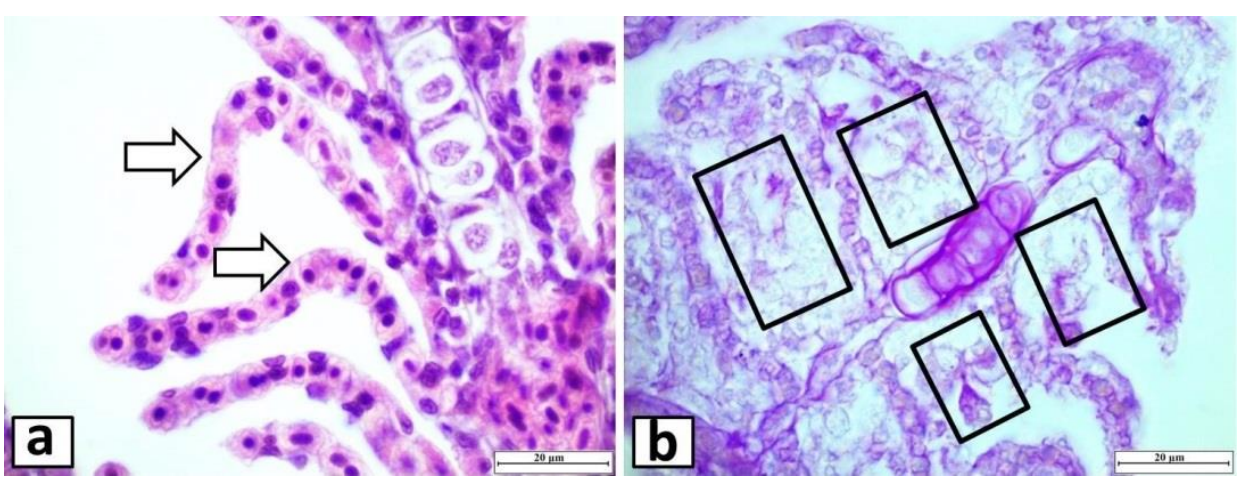

Figure 2. $1 \mathrm{mg} / \mathrm{L}$ fonofos treatment group. a) Curling of secondary lamellae (white arrows), H-E, X100. b) Epithelial hyperplasia (rectangles), PAS, X100.

$2 \mathrm{mg} / \mathrm{L}$ fonofos exposed group exhibited severe curling of secondary lamellae, epithelial hyperplasia, desquamation, and epithelial lifting (Fig. 3.). 


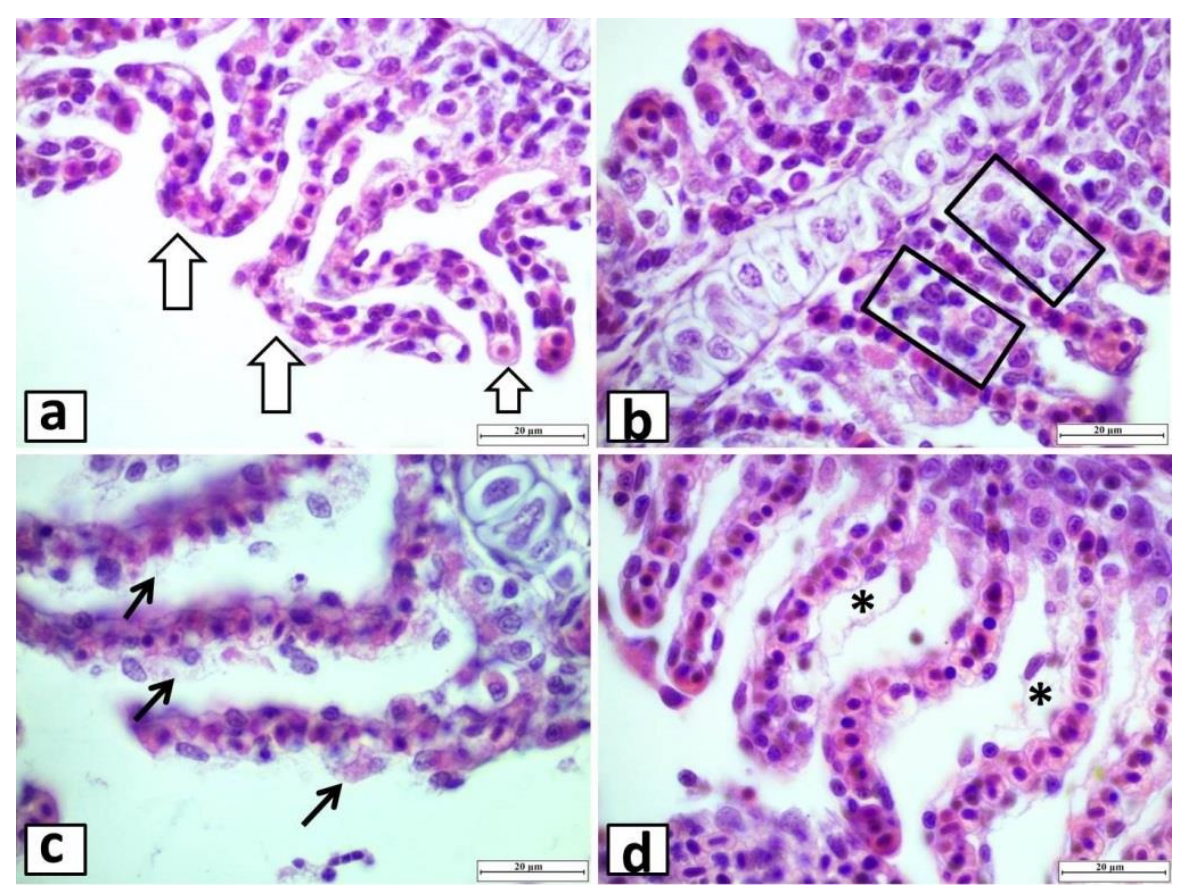

Figure 3. $2 \mathrm{mg} / \mathrm{L}$ fonofos treatment group. a) Curling of secondary lamellae (white arrows), H-E, X100. b) Epithelial hyperplasia (rectangels), H-E, X100. c) Desquamation (arrows), H-E, X100. d) Epithelial lifting (asterisks), H-E, X100.

$4 \mathrm{mg} / \mathrm{L}$ fonofos treatment caused curling of secondary lamellae, epithelial lifting, progressive epithelial hyperplasia, and lamellar fusion (Fig. 4.).

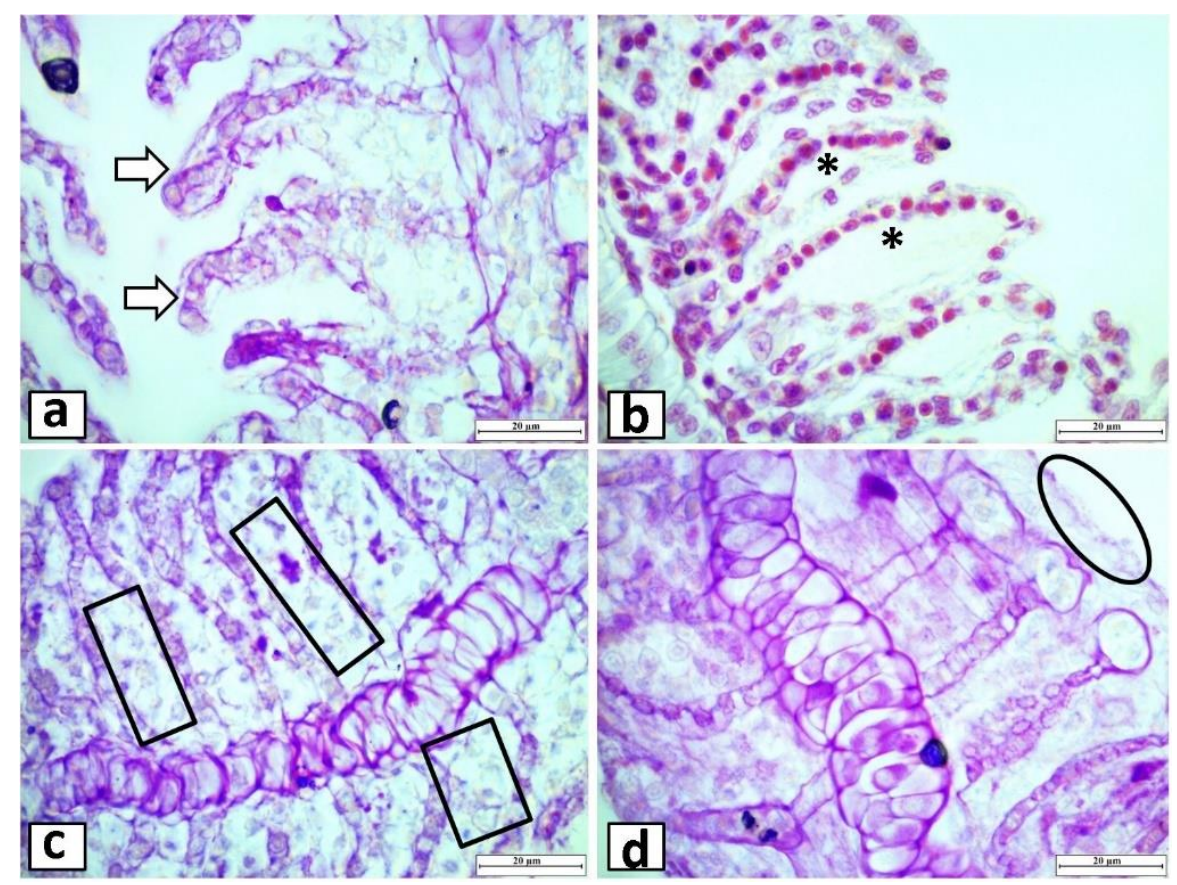

Figure 4. $4 \mathrm{mg} / \mathrm{L}$ fonofos treatment group. a) Curling of secondary lamellae (white arrows), PAS, X100. b) Epithelial lifting (asterisks), GT, X100. c) Epithelial hyperplasia (rectangles), PAS, X100. d) Lamellar fusion (ellipse), PAS, X100. 


\section{DISCUSSION}

This is the first study that revealed fonofos caused histopathological alterations in the gills of nontarget zebrafish. Fish are sensitive organisms that are directly affected by environmental contaminants or pollutants, so they are useful indicators for monitoring the effects of chemicals in aquatic environments $[14,15]$. Histopathological observations have been widely used to prove the damage of xenobiotics to a specific tissue rapidly. Various staining methods could be used to mark or highlight the special departments of the tissue, so in this study we performed GT and PAS methods in addition to H-E staining in parallel with the study of Adalı and Koca [16]. However, no significant pathology was noted in particular structures just as in red blood cells indicated by GT or in cartilage reacted with PAS, thus only general gill morphology was evaluated after fonofos exposure. Several reports are examining the histopathological alterations in teleost fish gills caused by various $\mathrm{OP}$ pesticides. Malathion exposure gave rise to necrosis and desquamation of secondary lamellar epithelium, epithelial lifting, intraepithelial edema, a fusion of adjacent secondary lamellae, disorganization, and rupture in secondary lamellae, hypertrophy and hyperplasia of epithelial cells in the gills of Gambusia affinis [17]. Oreochromis mossambicus gills were also affected by malathion treatment. The authors noted thickening of secondary lamellae, hemorrhage at primary lamellae, epithelial lining in the tips, lamellar aneurysm, lifting up of epithelium, deformation of the cartilage core, erosion and curling of secondary lamellae in O. mossambicus [18]. Cirrhinus mrigala gills exhibited epithelial hyperplasia, aneurysm, epithelial necrosis, desquamation, epithelial lifting, edema, lamellar fusion, and curling of secondary lamellae after monocrotophos exposure [19]. Dichlorvos caused hyperplasia, desquamation, necrosis, epithelial lifting, edema, lamellar fusion, collapsed secondary lamellae, and aneurysm in the secondary lamellae of C. mrigala [3]. Trichlorfon treatment gave rise to hyperplasia, swelling of blood sinuses in the secondary lamellae, subepithelial edema, lamellar fusion, and blood congestion in the gills of Piaractus mesopotamicus [20]. Labeo rohita gills showed epithelial lifting, lamellar fusion, and epithelial necrosis after profenofos treatment [15]. Chlorpyrifos exposure caused hyperplasia, hemorrhage and necrosis at primary lamellae, intraepithelial edema, destruction of epithelial lamella and epithelial lifting in Salmo trutta caspius gills [21].

In the present study fonofos adversely affected the gills of zebrafish and the alterations were noted as epithelial lifting, curling of secondary lamellae, desquamation, epithelial hyperplasia, and lamellar fusion. All histopathological changes observed in the gills were in a concentration-dependent manner.

In conclusion, fonofos caused acute toxic effects in zebrafish gills. Gills have critical roles in the metabolism of fish and fonofos exposure may destroy the function of gills. It is evident that fonofos is a threat to non-target organisms living in aquatic ecosystems.

\section{Acknowledgment}

This study was represented as a poster presentation in International Congress of Health and Environment (2017) in Adana-Turkey.

\section{REFERENCES}

[1]. Fairchild, J. F., Little, E. E., Huckins, J. N. Aquatic hazard assessment of the organophosphate insecticide fonofos. Archives of Environmental Contamination and Toxicology, 22-4 (1992) 375-379.

[2]. Costa, L.G. Current issues in organophosphate toxicology. Clinica Chimica Acta, 366-1 (2006) 1-13.

[3]. Velmurugan, B., Selvanayagam, M., Cengiz, E.I., Unlu, E. Histopathological changes in the gill and liver tissues of freshwater fish, Cirrhinus mrigala exposed to dichlorvos. Brazilian Archives of Biology and Technology, 52-5 (2009) 1291-1296. 
[4]. Murthy, K. S., Kiran, B. R., Venkateshwarlu, M. A review on toxicity of pesticides in fish. International Journal of Open Scientific Research, 1-1, (2013) 1536.

[5]. Deb, N., Das, S. Chlorpyrifos toxicity in fish: A Review. Current World Environment, 8-1, (2013) 77-84.

[6]. Ullah, S., Zorriehzahra, M. J. Ecotoxicology: a review of pesticides induced toxicity in fish. Advances in Animal and Veterinary Sciences, 3-1, (2015) 40-57.

[7]. U.S. EPA. (2008). Health Effects Support Document For Fonofos. Washington, DC: US Environmental Protection Agency. Available:

https://www.epa.gov/sites/production/files/ 2014-

09/documents/health_effects_support_docu ment_for_fonofos.pdf [accessed 16 May 2018].

[8]. Mahajan, R., Blair, A., Lynch, C.F., Schroeder, P., Hoppin, J.A., Sandler, D.P., Alavanja, M.C. Fonofos exposure and cancer incidence in the agricultural health study. Environmental Health Perspectives, 114-12 (2006) 1838-1842.

[9]. Lele, Z., Krone, P.H. The zebrafish as a model system in developmental, toxicological and transgenic research. Biotechnology Advances, 14-1 (1996) 5772.

[10]. Dai, Y.J., Jia, Y.F., Chen, N., Bian, W.P., Li, Q.K., Ma, Y.B., Chen, Y.L., Pei, D.S. Zebrafish as a model system to study toxicology. Environmental Toxicology and Chemistry, 33-1 (2014) 11-7.

[11]. Machado, M.R., Fanta, E. Effects of the organophosphorous methyl parathion on the branchial epithelium of a freshwater fish Metynnis roosevelti. Brazilian Archives of Biology and Technology, 46-3 (2003) 361372.

[12]. Gröner, F., Höhne, C., Kleiner, W., Kloas, W. Chronic diclofenac exposure affects gill integrity and pituitary gene expression and displays estrogenic activity in nile tilapia
(Oreochromis niloticus). Chemosphere, 166, (2017) 473-481.

[13]. Presnell, J.K., Schreibman, M.P. and Humason, G.L., Humason's animal tissue techniques. Johns Hopkins University Press. 1997

[14]. Lakra, W.S., Nagpure, N.S. Genotoxicological studies in fishes: a review. Indian Journal of Animal Sciences, 79-1 (2009) 93-97.

[15]. Nataraj, B., Hemalatha, D., Rangasamy, B., Maharajan, K., Ramesh, M. Hepatic oxidative stress, genotoxicity and histopathological alteration in fresh water fish Labeo rohita exposed to organophosphorus pesticide profenofos. Biocatalysis and Agricultural Biotechnology, 12 (2017) 185-190.

[16]. Adali, Y., Koca, Y.B. Effects of pollution on some tissues of fish collected from different regions of Büyük Menderes river: A histopathological study. Journal of Environmental Protection and Ecology, 172 (2016) 477-487.

[17]. Cengiz, E.I., Ünlü, E. Histopathology of gills in mosquitofish, Gambusia affinis after long-term exposure to sublethal concentrations of malathion. Journal of Environmental Science and Health - Part B Pesticides, Food Contaminants, and Agricultural Wastes, 38-5 (2003) 581-589.

[18]. Subburaj, A., Jawahar, P., Jayakumar, N., Srinivasan, A., Ahilan, B. Acute toxicity bioassay of Malathion ( EC 50\%) on the fish, Oreochromis mossambicus (Tilapia) and associated histological alterations in gills. Journal of Entomology and Zoology Studies, 6-1 (2018) 103-107.

[19]. Velmurugan, B., Selvanayagam, M., Cengiz, E.I., Unlu, E. The effects of monocrotophos to different tissues of freshwater fish Cirrhinus mrigala. Bulletin of Environmental Contamination and Toxicology, 78-6 (2007) 450-454.

[20]. Mataqueiro, M.I., Nakaghi, L.S.O., De Souza, J.P., Da Cruz, C., De Oliveira, G.H., Urbinati, E.C. Histopathological changes in the gill, liver and kidney of pacu (Piaractus 
mesopotamicus, Holmberg, 1887) exposed to various concentrations of trichlorfon. Journal of Applied Ichthyology, 25-1 (2009) 124-127.

[21]. Adel, M., Dadar, M., Khajavi, S.H., Pourgholam, R., Karimí, B., Velisek, J.
Hematological, biochemical and histopathological changes in Caspian brown trout (Salmo trutta caspius Kessler, 1877) following exposure to sublethal concentrations of chlorpyrifos. Toxin Reviews, 36-1 (2017) 73-79. 